\title{
A Novel Strain of Planomicrobium Isolated from Paper Mill and its Capacity of Cellulose Degradation
}

\author{
Rongxia Zhuge, ${ }^{\mathrm{a}}$ Qiang Cheng, ${ }^{\mathrm{b}}$ Luyu Mei, ${ }^{\mathrm{a}}$ Xiuli Song, ${ }^{\mathrm{a}}$ and Liuxin Shi ${ }^{\mathrm{a}, \mathrm{c}, \mathrm{d}, *}$ \\ A novel strain, designated $\mathrm{WH} 2-56$, was isolated from a slime sample \\ collected from a paper company along the Yangtze River during March, \\ 2018. Phylogenetic analyses based on 16S rRNA gene sequences \\ revealed that strain $\mathrm{WH} 2-56$ was related to members of the genus \\ Planomicrobium. Cellulolytic activity of the sample was screened and \\ confirmed by Congo red-polysaccharide interactions and examined by \\ broth culture using filter paper (FP) with no starch as the sole carbon \\ source. Field emission scanning electron microscopy (FE-SEM) was used \\ to confirm the delicate morphological changes of FP during bio- \\ degradation. Different cellulosic materials were used to measure \\ biodegradation effects and optimum incubation conditions. The activity of \\ FPase and carboxymethyl cellulase (CMCase) were checked by 3,5- \\ dinitrosalicylic acid (DNS agents) with different carbon sources, which \\ showed a peak at $0.62 \mathrm{U} / \mathrm{mL}$ of CMCase on day 4 , and at $0.38 \mathrm{U} / \mathrm{mL}$ of \\ FPase on day 5.
}

Keywords: Cellulose degradation; Carbon metabolism; Planomicrobium; Cellulase activity

Contact information: a: Jiangsu Co-Innovation Center for Efficient Processing and Utilization of Forest Resources, Nanjing Forestry University, Nanjing, 210037,China; b: Key Laboratory of Forest Genetics \& Biotechnology, MED, Nanjing Forestry University, Nanjing, 210037, China; c: Limerick Pulp and Paper Centre, University of New Brunswick, Fredericton, New Brunswick, Canada E3B 5A3; d: Jiangsu Provincial Key Lab of Pulp and Paper Science and Technology, Nanjing Forestry University, Nanjing, 210037, China; *Corresponding author: shiliuxin@njfu.edu.com

\section{INTRODUCTION}

Planomicrobium were isolated and proposed 100 years ago, variously from the Korean traditional fermented seafood, Antarctic Sea ice, coastal sediment, frozen food, cold desert, glacier, diesel oil, and sulfurous spring (Van and Kazuo 1985; Junge et al. 1998; Yoon et al. 2001; Romano et al. 2003; Dai 2005; Mayilraj et al. 2005; Zhang et al. 2009; Das and Tiwary 2014). These are extreme, hypersaline, and humid environments, indicating the high tolerance of the strain toward its environment. In different growth phases of the genus, its shape transforms into cocci, rods, or a mixture of both. In addition to the remarkable activity of lipase, protease, and the stable protection for plants from heavy metals and organic contaminants (Liu et al. 2013; Das and Tiwary 2014; Jin et al. 2016; Teymouri et al. 2016), its biodegradation potential on cellulose can also highlight the importance of the functions of ecosystem services that this genus provides. There has been a lack of attention to such issues in the published literature.

Paper mills are an appropriate and adaptable environment for providing bacteria and fungus on development, reproduction, and nutrition (Pokhrel and Viraraghavan 2005; Roest K et al. 2005; Zwieten et al. 2010; Shi et al. 2018; Su et al. 2018; Zainith et al. 2019). The present work represents the first report of Planomicrobium isolated from a paper machine along the Yangtze River in China, and it was expected to have 
biodegradation ability. There are diverse protocols to efficiently isolate and characterize cellulolytic microorganisms. One common method employs carboxymethyl cellulose with dye (CMC-Congo red) and filter paper, used as sole carbon source, which is degraded by cellulolytic microorganisms (Pointing 1999; Kameshwar and Qin 2018).

Cellulose, a linear polymer of 500 to 15000 glucose units that are linked by $\beta-1,4$ bonds, constitutes up to $45 \%$ of the dry weight of biomass (Pérez et al. 2002; Young et al. 2014; Mathews et al. 2015); it comprises a large proportion of agricultural waste (Lynd et al. 2002). For environmental protection, the use of renewable resources as substitutes for nonrenewable ones is of strategic significance (Fan et al. 2017), especially the reutilization of cellulose-rich agriculture wastes, which have massive annual production (Guo et al. 2010). Its linear chains and microcrystalline structure make cellulose a resistant material (Hamid et al. 2015). As the interest in developing cellulose-based material has increased, research exploring cellulolytic microorganisms has expanded; these microbes play a key role in maintaining all significant nutrient cycles (Chen 2014), especially the global carbon cycle (McDonald et al. 2012). Moreover, cellulose biodegradation is perceived as an indispensable process to replenish the carbon content of soil (Feng et al. 2007; Maki et al. 2009; Stursova et al. 2012).

Biodegradation of the complex polymer is facilitated by diverse cellulase enzyme polymer produced by microorganisms. For example, bacteria use diverse cellulolytic enzymes to achieve the degradation of cellulose for using it as the primary source of their main biochemical cycles, and in general the carbon cycles. Microbiological and enzymatic treatment is expected to be safe, green, and environmentally friendly (Bilal et al. 2017), but it is influenced by the strain type, conditions of cultivation, and carbon sources in the medium (Niranjane et al. 2007; Gao et al. 2008). Even bacteria with low cellulolytic capacity can be activated in the presence of an easily metabolized carbon source (Amore et al. 2013; Yamakawa et al. 2013; Raulo et al. 2016), which is due to the gene expression patterns of their enzymes.

In this study, three pure cellulosic materials - filter paper (FP), microcrystalline cellulose (MC), and 1\% hardwood pulp (HP) - and two agricultural wastes with a different content of components - wheat straw (WS) and corn stalk (CS) - were selected to be the sole carbon source to evaluate the utilization and enzyme activities.

\section{EXPERIMENTAL}

\section{Slime Sample and Isolation Procedure}

Microbes diversity can have subtle differences with different longitude and latitude during different seasons (Tirado et al. 2016). To collect samples as completely as possible, slime samples were collected from four pulp mills of different geographic position along the Yangtze River and different end-product including cultural, living, and wrapping paper. Also, the sampling time were selected in March, June, July, and December of 2018. Samples were immediately placed on ice and later stored at $4{ }^{\circ} \mathrm{C}$.

\section{Congo Red Isolation, Purification, and Screening}

Congo red dye can be use for a quick and clear method to screen cellulolytic microbes (Taha et al. 2015). Congo red medium was composed as follows (Teather and Wood 1982; Kasana et al. 2008; Gupta et al. 2012): sodium carboxymethyl cellulose, 5.0 $\mathrm{g}$; ammonium sulfate, $2.0 \mathrm{~g}$; potassium dihydrogen phosphate, $1 \mathrm{~g}$; heptahydrate 
magnesium sulfate, $0.5 \mathrm{~g}$; sodium chloride, $0.5 \mathrm{~g}$; sodium nitrate, $1 \mathrm{~g}$; peptone, $0.5 \mathrm{~g}$; yeast extract, $0.5 \mathrm{~g}$; Congo red, $0.2 \mathrm{~g}$; agar, $13 \mathrm{~g}$, distilled water $1 \mathrm{~L}$; $\mathrm{pH} 7$.

The isolation procedure was performed using cultures from the paper slime samples that showed Congo red-decolorizing activity. The cultures in which decolorization were observed were subsequently isolated and transferred to fresh medium. For purification, the transfer was repeated several times until the isolates were pure in morphology. Isolates were inoculated onto three spots to the Congo red dye medium, within a certain distance per plate, and then incubated at $37{ }^{\circ} \mathrm{C}$ for three days. Cellulose degradation was identified via a legible transparent zone around the colony on a red background (Lu et al. 2004; Sangma and Thakuria 2018). The hydrolysis capacity (HC) was proportional to the value of the ratio between the diameter of the zone and colony, which can screen betterperformance ones. A higher ratio indicates higher potential hydrolysis capacity.

\section{Morphologies of FP}

Filter paper (FP) was used to make a further examination. The medium recipe was similar to the medium above, which utilize FP to replace CMC-Na as the sole carbon source, with the dye and agar removed. Erlenmeyer flasks $(250 \mathrm{~mL})$ containing $100 \mathrm{~mL}$ of autoclaved $\left(16 \mathrm{~min}, 120^{\circ} \mathrm{C}\right)$ medium were inoculated with $5 \%(\mathrm{v} / \mathrm{v})$ pregrown culture $(0.74$ $\mathrm{mg}$ protein $/ \mathrm{mL})$ in $\log$ phase. The flasks were incubated at $37{ }^{\circ} \mathrm{C}$ on a rotary shaker $(150$ $\mathrm{rpm}$ ) for a week. The surface morphological transformations of FP inoculated by the strains for 3 and 6 days were checked by field emission scanning electron microscopy (FE-SEM, JEOL, Tokyo, Japan) to identify the structural changes of cellulose during the cultivation, while the uninoculated FP group was used as control.

\section{Biodegrading Efficiency by WH2-56}

Metabolic and cellulase activity

Isolates were pregrown to an optical density at $600 \mathrm{~nm}$ of 1.0 , then washed in M9 buffer twice before being inoculated into the fermentation broth $(100 \mathrm{~mL}$ in $250 \mathrm{~mL}$ conical flasks and orbital shaking at $180 \mathrm{r} / \mathrm{min}$ ). The fermentation broths were the same as Congo red medium, with no dye or agar. Crude enzymes were obtained every $24 \mathrm{~h}$ by taking samples from the cultures and centrifuging at $6000 \mathrm{r} / \mathrm{min}$ for $15 \mathrm{~min}$ at $4{ }^{\circ} \mathrm{C}$ to remove suspended solids. The supernatants were filtered through a sterile $0.22 \mu \mathrm{m}$ pore polyvinylidene fluoride membrane and then used as the base to monitor the activity of total cellulase activity (FPase) (King et al. 2009; Oszust et al. 2017) and carboxymethyl cellulase (CMCase) (Miller et al. 1960; Zhao et al. 2008) by 3,5-dinitrosalicylic acid (DNS agents) with different substrates, which showed the cellulose-degrading capacities of the microbes. The standard curve was constructed via $1 \mathrm{~g} / \mathrm{L}$ glucose, and the absorption subsequently determined at $550 \mathrm{~nm}$. The tube with no crude enzymes was used as blank. All tests were replicated three times. Activities of the enzyme were expressed by international units (U), which were defined as the amount of cellulose needed per minute to produce $1 \mu \mathrm{mol}$ glucose. All assays were carried out in triplicate.

The metabolic activity of microorganisms was measured through the ratio of the respiration (OD $490 \mathrm{~nm}$ ) and mycelium growth (OD $750 \mathrm{~nm}$ ), which compares the biomass development and the metabolic activity (Pinzari et al. 2014, 2016). The cultures were taken off for measuring the optical density of OD $490 \mathrm{~nm}$ and OD $750 \mathrm{~nm}$ every $24 \mathrm{~h}$ during the incubation period. 


\section{Weight loss ratio}

Three different cellulosic material, hardwood pulp (HP), microcrystalline cellulose (MC), and FP were prepared to a final concentration of $1 \%$ in the broth medium. Pre-grown WH2-56 was inoculated $2 \%(\mathrm{v} / \mathrm{v})$ to the different cellulosic media. In consideration of the influence of environmental parameters, each conical flask was prepared at $\mathrm{pH} 7.0$ and incubated at different temperatures $\left(28,37\right.$, and $\left.45^{\circ} \mathrm{C}\right)$, adjusted to different $\mathrm{pH}(6,7,8)$, and incubated at $37{ }^{\circ} \mathrm{C}$ for a week. All broth media were taken out every $24 \mathrm{~h}$ for measurement of $\mathrm{pH}$, enzyme activities, and the concentration of total protein, which was measured by ultraviolet spectrophotometry at $280 \mathrm{~nm}$. After one week of incubation, all cultures were filtered, and the residual cellulose was washed with diluted hydrochloric acid and heated at $60{ }^{\circ} \mathrm{C}$ until it reached a constant weight. The weight loss ratio $(V)$ was calculated as follows,

$$
V=\frac{w^{*}-w}{w^{*}}
$$

where $w$ is weight of residue cellulose after a two-week incubation and $w^{*}$ is the original addition of cellulosic material.

\section{Using different biomass material as carbon source}

To evaluate different carbon sources utilization and enzyme activities, agricultural wastes with different cellulose contents were added to the carbon source choices in subsequent operations. As the FP medium recipe mentioned before, wheat straw (WB), corn stalk (CS), and glucose (used as a control, CTRL) were used as the sole carbon source $(1 \% \mathrm{w} / \mathrm{v})$ to measure the cellulolytic ability of WH2-56. Wheat straw and corn stalk were washed, dried, and cut to 2 to $3 \mathrm{~cm}$ length before using the Wiley mill. Particles of sizes of 40- to 60-mesh were collected in sealed plastic bags at room temperature. WH2-56 were inoculated to the broth medium with $5 \%$ inoculum, and uninoculated samples were used as controls. The analyses were performed in analytical triplicate for each of the biological duplicate experiments $(n=6)$. After a two-week incubation, the components (cellulose, klason lignin, acid solution, and ash) of the biomass were determined as described previously (Taniguchi et al. 1982; Zhu et al. 2009), and the enzyme activities were measured every $24 \mathrm{~h}$.

\section{$16 S$ rDNA Sequence Analysis}

The DNA extraction was achieved by kit (Bioteke, Nanjing, China), and then stored at $-20{ }^{\circ} \mathrm{C}$ for further analysis. The $16 \mathrm{~S}$ rDNA fragment was amplified by polymerase chain reaction (PCR) with a pair of universal primers, 27f and 1392r. The PCR mixture was composed of $5 \mu \mathrm{L}$ of $10 *$ Ex Taq buffer, $4 \mu \mathrm{L}$ of dNTP, $3 \mu \mathrm{L}$ of DNA extract as a template, $2 \mu \mathrm{L}$ of each primer $(10 \mu \mathrm{M})$, and $0.5 \mu \mathrm{L}$ of rTaq, and water up to a volume of $50 \mu \mathrm{L}$. The amplification protocol was as follows: initial denaturation at $94{ }^{\circ} \mathrm{C}$ for $5 \mathrm{~min} ; 33$ cycles of denaturation at $94{ }^{\circ} \mathrm{C}$ for $30 \mathrm{~s}$, primer annealing at $55^{\circ} \mathrm{C}$ for $30 \mathrm{~s}$, and extension at $72{ }^{\circ} \mathrm{C}$ for $1.5 \mathrm{~min}$; and final extension at $72{ }^{\circ} \mathrm{C}$ for $7 \mathrm{~min}$. The PCR product was subjected to electrophoresis on a 1\% agarose gel, and the $1200 \mathrm{bp}$ band was purified by a PCR purification kit (Tiangen, Beijing). The sequencing procedure was achieved by GenScript Biotech Corp., Nanjing, China, and the data was compared to the NCBI database in BLAST (http://www.ncbi.nlm.nih.gov/BLAST). 


\section{RESULTS AND DISCUSSION}

\section{Isolation, Purification and Screening}

After inoculating to the Congo red-CMCNa plate for 3 days, isolates WH2-56 showed a great performance with a high value of the diameter ratio, which means a higher degradation capacity of cellulose. An automated colony-counter was used to take highdefinition photos (Fig. 1a) of the plates, which made the legible transparent zone around the colony easy to observe. WH2-56 had a smaller colony and larger transparent zone than other strains; its high ratio (average 16.79 as) identified it as a potential cellulolytic genus. Single colonies of WH2-56 inoculated to LB plate (Fig. 1b) were circular, smooth, slight convex compared to the edge and pale orange in color.

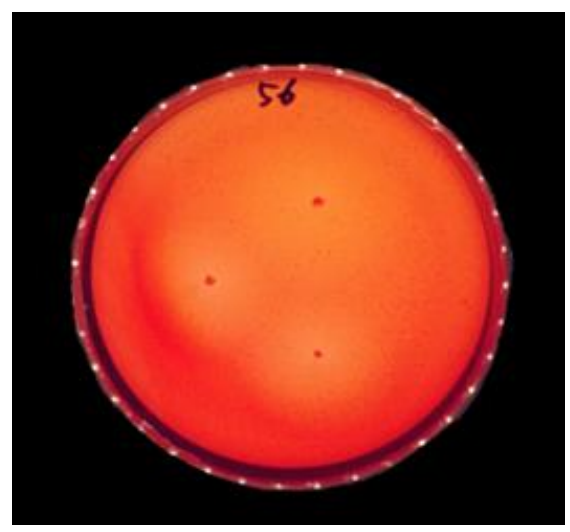

(a)

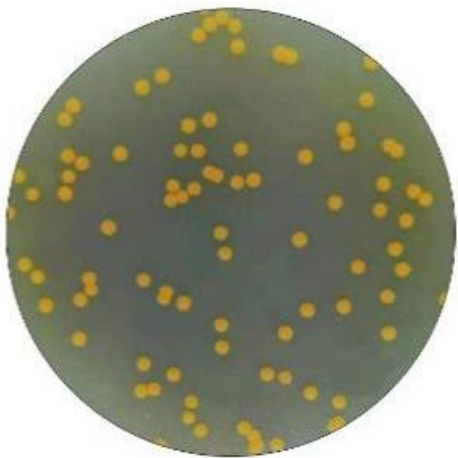

(b)

Fig. 1. Photos of $\mathrm{WH} 2-56$ (a) after 3 days incubation in Congo red plates by automated colonycounter; colonies cultured on LB plate (b)

To avoid the ambiguity caused by visual interpretation of FP surface (Pointing 1999), FE-SEM was employed for a precise distinction result. FE-SEM images of the control fiber showed a surface with flat and close edge, while the experimental ones showed an embossed, serrated, and cracked state, especially on the sixth day, which means the growth of WH2-56 opened up the space of pores between the fibers of FP (Fig. 2). Because FP was the sole carbon source in the medium, the activities of cellulase enzyme were better activated and much easier to observe through FP degradation. This phenomenon verified the fact that isolate $\mathrm{WH}-56$ broke the surface and structure of cellulose, which confirmed its ability to degrade cellulose.

\section{Biodegradation of Cellulose by Wh2-56}

When comparing the different carbon sources, the microcrystalline cellulose group performed a higher degradation effect among the three cellulosic materials, while the filter paper group showed weaker degradation. This result may reflect the contact area between isolate and cellulose fibers, and the content of cellulose of different materials. Environmental parameters influence the degradation efficiency and the growth of cultures. With initial concentration of $10.0 \mathrm{~g} / \mathrm{L}$ of carbon source, there was an increased removal ratio of microcrystalline cellulose up to $52.1 \%$ at $\mathrm{pH}$ 6.0. The optimum $\mathrm{pH}$ value was around 6.0 at a constant incubation temperature (Fig. 3a). In line with the $\mathrm{pH}$ value, the best temperature for biodegradation was $37^{\circ} \mathrm{C}$, which was related to the growth of $\mathrm{WH} 2$ 56. 


\section{bioresources.com}

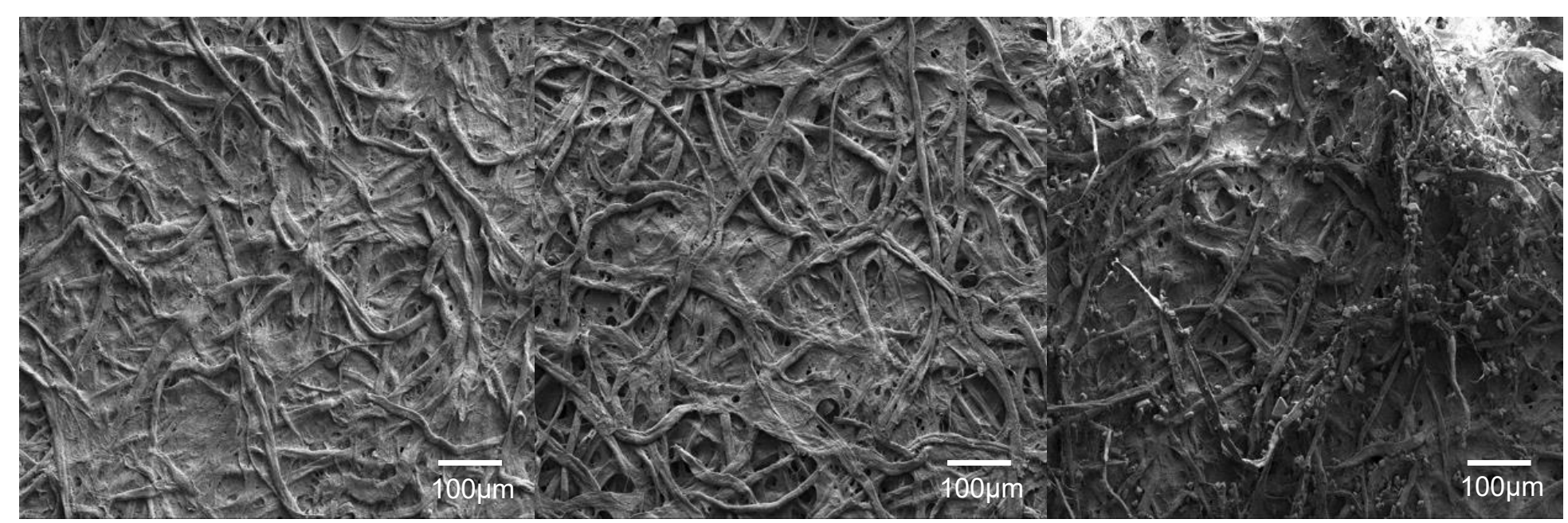

(a)

(b)

(c)

Fig. 2. FE-SEM images of FP samples of the control (a), inoculated by WH-56 after 3 days (b) and 6 days (c). The magnification was 100 times. 


\section{bioresources.com}

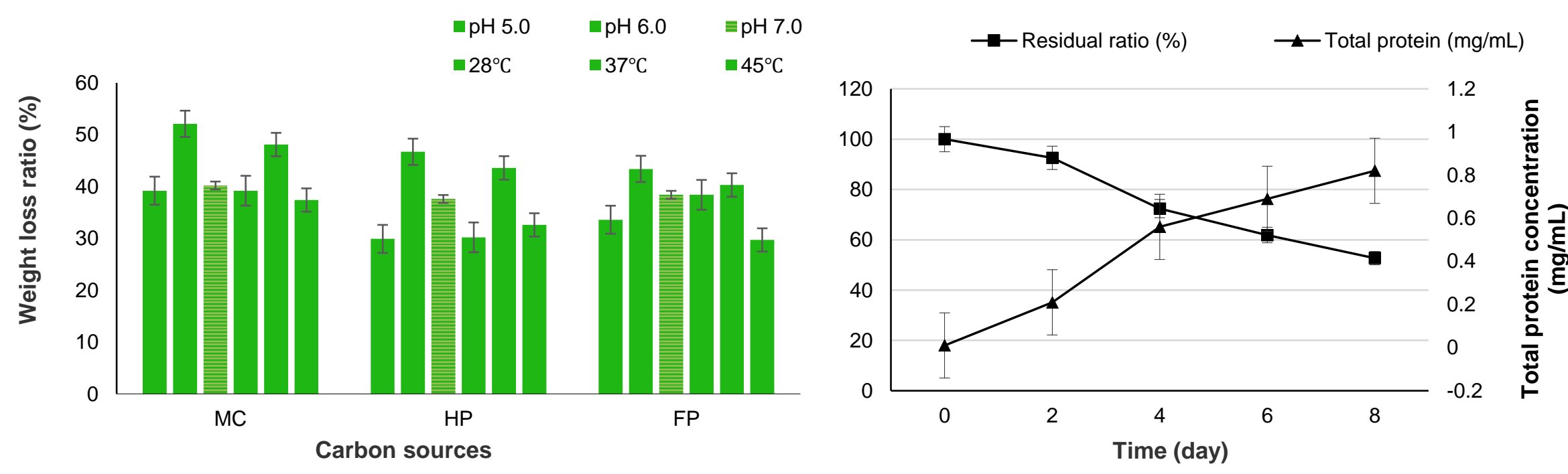

(a)

(b)

Fig. 3. (a) the weight loss ratio of three carbon sources in different incubation condition of $\mathrm{pH}$ and temperature; (b) time course of biodegradation of microcrystalline cellulose and protein concentration under optimized incubation condition $\left(37^{\circ} \mathrm{C}, \mathrm{pH} 6.0\right)$. Error bars indicate $95 \%$ confidence intervals 
The residual ratio of cellulose and total protein concentration in the optimum conditions $\left(37^{\circ} \mathrm{C}, \mathrm{pH} 6.0\right)$ are shown in Fig. 3b. As time went by, the degradation ratio was in proportion to the protein content of the culture, which reflected to the effect of enzyme efficiency. Maximum changing rates were occurred on day 3, both the protein concentration and degradation ratio exhibited a sharp increase, which may reflect the enzymatic and metabolic activities. Residual ratio of cellulose reached $52.7 \%$ on day 8 , while total protein concentration increased to $0.82 \mathrm{mg} / \mathrm{mL}$.

As for the selected agricultural wastes, native corn stalk was composed of cellulose (39.3\%), hemicellulose (24.8\%), Klason lignin (20.9\%), ash and others $(10.2 \%)$, and acidsoluble lignin $(4.8 \%)$, while wheat straw was $37.1 \%, 27.8 \%, 14.6 \%, 11.2 \%$, and $9.3 \%$, respectively. After incubation, all the main components of agriculture fuel had partially degraded (Table 1), which resulted from the growth of WH2-56 and carbon source utilization. In corn stalk groups, $18.4 \%$ cellulose, $13.3 \%$ hemicellulose, and $7.3 \%$ Klason lignin were degraded, indicating that $\mathrm{WH} 2-56$ can promote the degradation of other components in agricultural wastes.

Table 1. Residual Amounts of Components of Carbon Source after Fortnight's Incubation

\begin{tabular}{|c|c|c|c|c|}
\hline \multirow{2}{*}{ Carbon Source } & \multicolumn{4}{|c|}{ Residual Amounts (\%) } \\
\cline { 2 - 5 } & Hemicellulose & Cellulose & $\mathrm{KL}$ & $\mathrm{AL}$ \\
\hline wheat straw & 90.5 & 88.2 & 95.4 & 87.0 \\
\hline corn stalk & 86.7 & 81.6 & 92.7 & 84.1 \\
\hline
\end{tabular}

*The initial agriculture waste content was $10 \mathrm{~g} \mathrm{~L}^{-1} . \mathrm{KL}$, Klason lignin; $\mathrm{AL}$, acid soluble lignin.

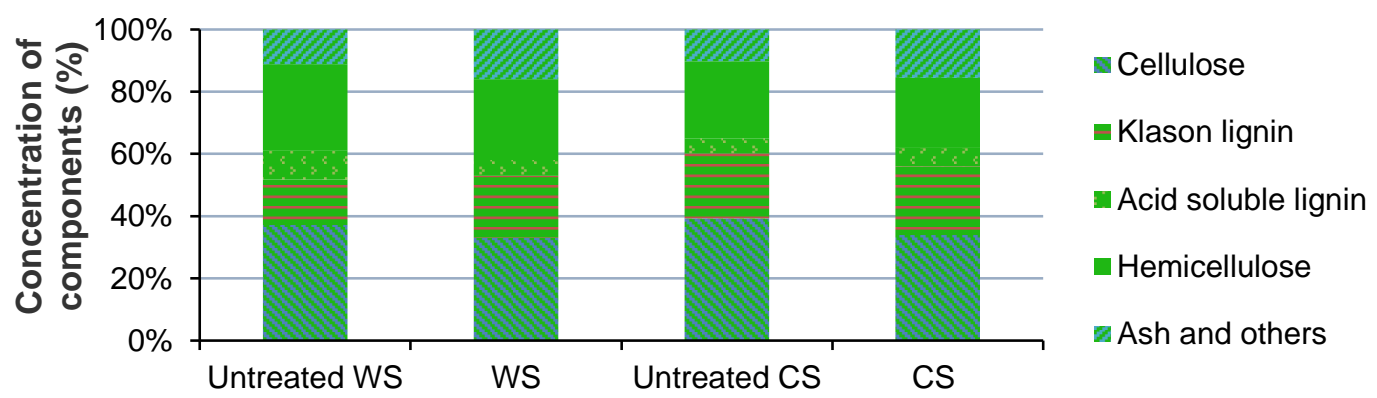

Fig. 4. Percentage changes of composition of component of agricultural waste after two-week incubation

The changes in the component content of WS (wheat straw) and CS (corn stalk) were clear. Compared with initial state, cellulose percentages of the total weight of WS and CS decreased $4.1 \%$ and $5.3 \%$ respectively, while ash increased $4.8 \%$ and $5.3 \%$ accordingly, which revealed the biodegradation by WH2-56 (Fig. 4). Cellulose content of the two agriculture wastes decreased twice as much as the hemicellulose, which indicated that the biodegradation of $\mathrm{WH} 2-56$ is selective and potential.

\section{Metabolic and Cellulase Activity}

FPase and CMCase were detected by DNS agent with FP-buffer and CMCNa solution as carbon source, respectively. Analyzing each enzymatic activity separately, the total cellulase enzyme (FPase) achieved a more steady fluctuation. The low FPase activity may related to the species-specific and carbon source-difference characteristics of cellulase 
(Wen et al. 2005); wheat bran as carbon source acquired positive results on FPase activity (Brijwani et al. 2010; Oberoi et al. 2010; Dhillon et al. 2011). The reaction between mineral substances and mediums, the nature of carbon source which added to the medium and the energy-consuming process of enzymatic products may lead to different degrees on inhibition in expression of relevant enzymatic genes (Amore et al. 2013).

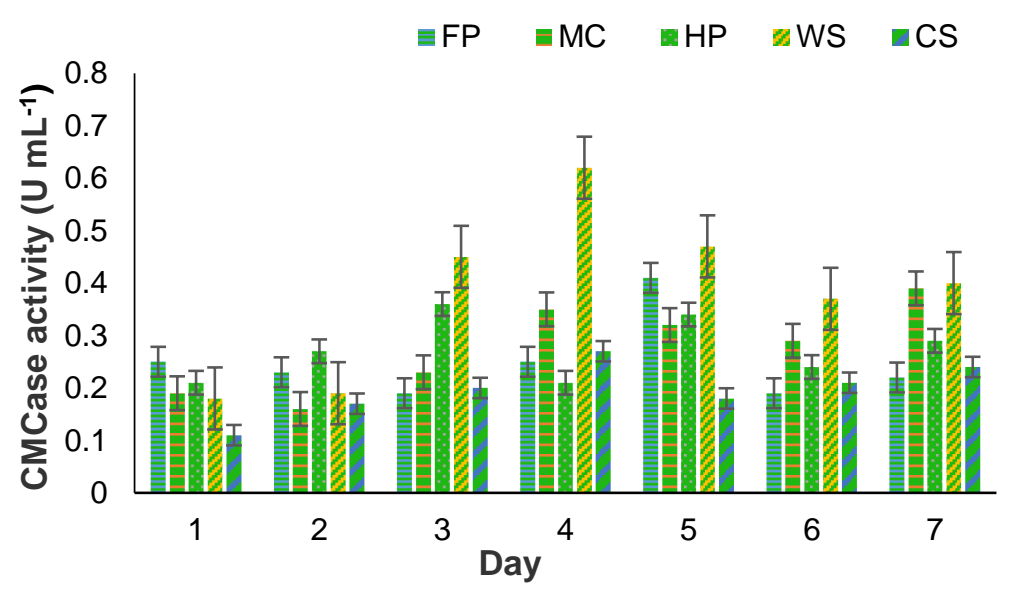

(a)

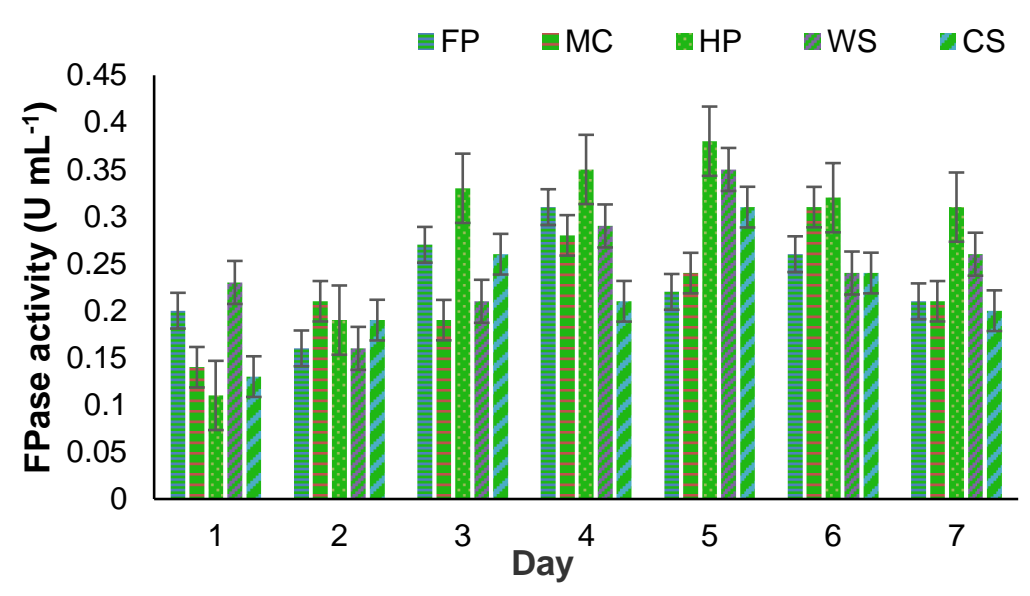

(b)

Fig. 5. Time course of CMCase activity (a) and FPase (b) under five different carbon source, with the modified incubating condition mentioned above. Error bar means $\pm \mathrm{SD}$ (standard deviation), $\mathrm{n}$ $=3$.

The results showed subtle differences between five carbon sources, except for the HP sample, which peaked at $0.47 \mathrm{U} / \mathrm{mL}$ on day 5 (Fig. 5, a). By comparison with the drop on day 5 of CMCase, FPase still performed a stable promotion, which revealed the synergistic effects of other cellulases secreted by WH2-56. Activities of CMCase appeared clear discrimination among different carbon sources, with the peak at $0.62 \mathrm{U} / \mathrm{mL}$ of WS on day 4 (Fig.5, left) and $0.41 \mathrm{U} / \mathrm{mL}$ of FP on day 5, which were higher than other carbon sources.

Analysing each carbon source separately, at the beginning of incubation, the WS medium presented a lower stage on CMCase, and then on day 3 it increased sharply to over twice times than the former day, which lasted until the end of culture period. Similarly, the FPase of HP medium performed a low value at the first two days and increased steadily to maintain over $0.3 \mathrm{U} / \mathrm{mL}$ during the whole period. Similar results occurred during the first 
three days of other carbon source mediums, which may relate to the decrease of $\mathrm{pH}$ value (around 6) of the fermentation broth (data not shown). Both the CMCase and FPase activity of CS medium observed were around $0.2 \mathrm{U} / \mathrm{mL}$ constantly, seemed not to be an easily metabolized carbon source compared with others in activating the expression of enzyme genes.

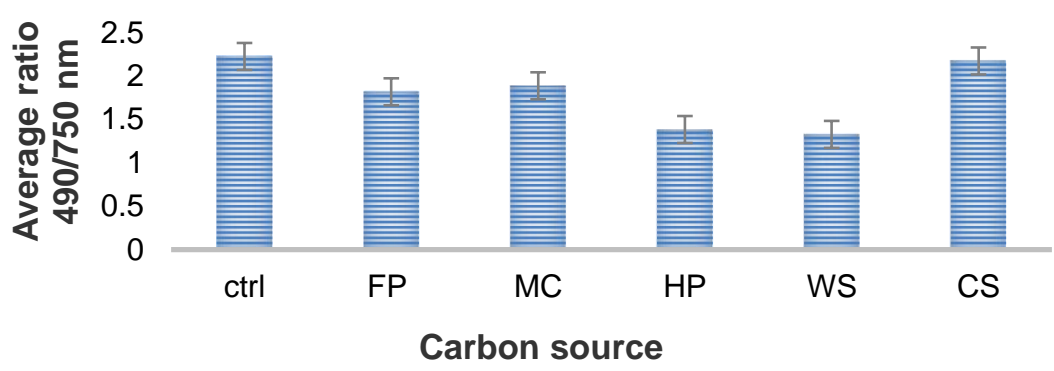

Fig. 6. Average ratio $490 / 750 \mathrm{~nm}$ of WH2-56 cultivated in five different carbon sources. A lower ratio indicates more efficient metabolism, which means the mycelium growth is higher than the metabolic activity

During incubation, metabolic activities were examined by the ratio $490 / 750 \mathrm{~nm}$ (Fig. 6) of samples taken every $24 \mathrm{~h}$. WH2-56 inoculated in 5 different carbon sources all had a better performance on metabolic efficiency than the control, while the results of CS were similar to the control. Compared with other carbon sources, the WS medium showed the most efficient metabolism, while the HP medium came second, which kept in line with the results of enzymatic activities to some extent.

\section{$16 S$ rDNA Sequencing}

Compared with NCBI database sequences, the closest phylogenetic relatives were Planomicrobium koreense JG07T, Planomicrobium sp. SCU63, and Planomicrobium sp. Y50 with $99.8 \%, 99.6 \%, 99.6 \%$ 16S rRNA gene sequence similarity, respectively. Because $99 \%$ similarity is sufficient to acquire a credible result regarding genus and species (Janda and Abbott 2009), phylogenetic analyses based on 16S rRNA gene sequences revealed that strain WH2-56 was related to members of the genus Planomicrobium. Since domestic research on this species has been insufficient, also in view of the sequence complexity, the identification of the strain cannot be determined conclusively by similarity, thus, we identified it as a novel strain of the member of Planomicrobium. The nucleotide sequences were submitted to the NCBI GenBank Databases under accession number MN475274.

\section{CONCLUSIONS}

1. The present work examined the potential biodegradation capacity on cellulose and also other components of agricultural wastes of WH2-56, which were related to the Planomicrobium genus and isolated from a paper mill along the Yangtze River.

2. The experiments were focused on the changing shapes during different growth stage, activities of lipase and proteinase of Planomicrobium strains, and the cellulosebiodegrading potential. 
3. The Planomicrobium sp. performed various levels of degradation and utilization effects on different carbon sources, especially the cellulose-based materials like agricultural wastes. This behavior of metabolism and utilization can be deemed as an indispensable and potential process to accelerate the carbon circle, degrade agricultural wastes, and replenish the carbon content of soil.

\section{ACKNOWLEDGMENTS}

This work was supported by grants from the Major Research Project of the Natural Science Foundation of Jiangsu Higher Education Institutions (No. 14KJA53002).

\section{REFERENCES CITED}

Amore, A., Giacobbe, S., and Faraco, V. (2013). "Regulation of cellulase and hemicellulase gene expression in Fungi," Curr. Genomics 14(4), 230-249. DOI: 10.2174/1389202911314040002

Bilal, M., Asgher, M., Parra-Saldivar, R., Hu, H., Wang, W., Zhang, X., and Hafiz, M.N. (2017). "Immobilized ligninolytic enzymes: an innovative and environmental responsive technology to tackle dye-based industrial pollutants - A review," Sci. Total Environ. 576, 646-659. DOI: 10.1016/j.scitotenv.2016.10.137

Brijwani, K., Oberoi, H. S., and Vadlani, P. V. (2010). "Production of a cellulolytic enzyme system in mixed-culture solid-state fermentation of soybean hulls supplemented with wheat bran," Process Biochem. 45, 120-128. DOI: 10.1016/j.procbio.2009.08.015

Chen, H. (2014). Biotechnology of Lignocellulose: Theory and Practice, Institute of Process Engineering, CAS, Beijing, China.

Dai, X. (2005). "Planomicrobium chinense sp. nov. isolated from coastal sediment, and transfer of Planococcus psychrophilus and Planococcus alkanoclasticus to Planomicrobium as Planomicrobium psychrophilum comb. nov. and Planomicrobium alkanoclasticum comb. nov.," Int J. Syst. Evol. Microb. 55(2), 699-702. DOI: 10.1099/ijs.0.63340-0

Das, R., and Tiwary, B. N. (2014). "Production of indole acetic acid by novel bacterial strain of Planomicrobium chinense isolated from diesel oil contaminated site and its impact on the growth of Vigna radiate," Eur. J. Sol. Sci. 62(5), 92-100. DOI: 10.1016/j.ejsobi.2014.02.012

Dhillon, G. S., Oberoi, H. S., Kaur, S., Bansal, S., and Kaur, S. K. (2011). "Valueaddition of agricultural wastes for augmented cellulase and xylanase production through solid-state tray fermentation employing mixed-culture of fungi," Ind. Crop. Prod 34, 1160-1167. DOI: 10.1016/j.indcrop.2011.04.001

Fan, J., Shen, J., Wang Q., Qian, X., Ren, Y., and Li, Ting. (2017). "Interaction between two oppositely charged starches in an aqueous medium containing suspended mineral particles as a basis for the generation of cellulose-compatible composites," Ind. Crop. Prod. 97, 417-424. DOI: 10.1016/j.indcrop.2016.12.048

Feng, Y., Duan, C. J., Pang, H., Mo, X. C., Wu, C. F., Yu, Y., Wei, J., Tang, J. L., and Feng, J. X. (2007). "Cloning and identification of novel cellulase genes from uncultured microorganisms in rabbit cecum and characterization of the expressed 
cellulases," Appl. Microbiol. Biotechnol. 75(2), 319-328. DOI: 10.1007/s00253-0060820-9

Gao, J., Weng, H., Zhu, D., Yuan, M., Guan, F., and Xi, Y. (2008). "Production and characterization of cellulolytic enzymes from the thermoacidophilic fungal Aspergillus terreus M11 under solid-state cultivation of corn stover," Bioresource Technol. 99, 7623-7629. DOI: 10.1016/j.biortech.2008.02.005

Guo, P., Zhu, W., Wang, H., Lu, Y., Wang, X., Zheng, D., and Cui, Z. (2010). "Functional characteristics and diversity of a novel lignocelluloses degrading composite microbial system with high xylanase activity," J. Microbiol. Biotechnol. 20, 254-264. DOI: 10.4014/jmb.0906.06035

Gupta, P., Samant, K., and Sahu, A. (2012). "Isolation of cellulose degrading bacteria and determination of their cellulolytic potential," Int. J. Microbiol. 2012(6)578925, 1-5. DOI: $10.1155 / 2012 / 578925$

Hamid, S. B. A., Islam, M. M., and Das, R. (2015). "Cellulase biocatalysis: Key influencing factors and mode of action," Cellulose 22, 2157-2182. DOI: $10.1007 / \mathrm{s} 10570-015-0672-5$

Janda, J. M., and Abbott, S. L. (2009). “The genus Aeromonas: Taxonomy, pathogenicity, and infection," Clin. Microbiol. Rev. 23, 35-73. DOI: 10.1128/CMR.00039-09

Jin, Y., Wang, Y., Xiao, L., and Lin, X. (2016). "Characterization of proteases from microbium sp. L-2 isolated from the gastrointestinal tract of Octopus variabilis (Sasaki)," Chin. J. Oceanol. Limn. 34(3), 559-566. DOI: 10.1007/s00343-016-5040-2

Junge, K., Gosink, J. J., Hoppe, H. G., and Staley, J. (1998). “Arthrobacter, Brachybacterium and Planococcus isolates identified from Antarctic sea ice brine. Description of Planococcus mcmeekinii. sp. nov.," Syst. Appl. Microbiol. 21(2), 306314. DOI: 10.1016/S0723-2020(98)80038-6

Kameshwar, A. K. S., and Qin, W. (2018). "Isolation and screening of cellulosedegrading microorganisms from different ecological niches," in: Cellulases. Methods in Molecular Biology, M. Lübeck (ed.), Humana Press, New York, pp. 47-56. DOI: 10.1007/978-1-4939-7877-9_4

Kasana, R. C., Salwan, R., Dhar, H., Dutt, S., and Gulati, A. (2008). "A rapid and easy method for the detection of microbial cellulases on agar plates using Gram's iodine," Curr. Microbiol. 57, 503-507. DOI: 10.1007/s00284-008-9276-8

King, B. C., Donnelly, M. K., Bergstrom, G. C., Walker, L. P., and Gibson, D. M. (2009). "An optimized microplate assay system for quantitative evaluation of plant cell walldegrading enzyme activity of fungal culture extracts," Biotechnol. Bioeng. 102, 10331044. DOI: $10.1002 /$ bit.22151

Liu, Q., Sun, S., Piao, M., and Yang J. (2013). "Purification and characterization of a protease produced by a Planomicrobium sp. L-2 from gut of Octopus vulgaris," Prev. Nutri. Food Sci.18(4), 273-279. DOI: 10.3746/pnf.2013.18.4.273

Lu, W. J., Wang, H. T., and Nie, Y. F. (2004). "Effect of inoculating flower stalks and vegetable waste with ligno-cellulolytic microorganisms on the composting process," J. Environ. Sci. Health (B) 39(5-6), 871-887. DOI: 10.1081/LESB-200030896

Lynd, L. R., Weimer, P. J., van, Z. W., and Pretorius, I. S. (2002). "Microbial cellulose utilization: Fundamentals and biotechnology," Microbiol. Mol. Biol. Rev. 66(3), 506577. DOI: 10.1128/MMBR.66.3.506-577.2002

Maki, M., Leung, K. T., and Qin, W. (2009). "The prospects of cellulase-producing bacteria for the bioconversion of lignocellulosic biomass," Int. J. Biol. Sci. 5(5), 500- 
516. DOI: 10.7150/ijbs.5.500

Mathews, S. L., Pawlak, J., and Grunden, A. M. (2015). "Bacterial biodegradation and bioconversion of industrial lignocellulosic streams," Appl. Microbiol. Biot. 99(7), 2939-2954. DOI: 10.1007/s00253-015-6471-y

Mayilraj, S., Prasad, G. S., Suresh, K., Saini, H. Shivaji, S., and Chakrabarti, T. (2005). "Planococcus stackebrandtii sp. nov. isolated from a cold desert of the Himalayas, India," Int. J. Syst. Evol. Microb. 55(1), 91-94. DOI:10.1016/S0966-3274(02)00064-3

McDonald, J. E., Rooks, D. J., and McCarthy, A. J. (2012). "Methods for the isolation of cellulose degrading microorganisms," Methods Enzymol. 510, 349-374. DOI: 10.1016/B978-0-12-415931-0.00019-7

Miller, G. L., Blum, R., Glennon, W. E., and Burton, A. L. (1960). "Measurement of carboxymethylcellulase activity," Anal. Biochem. 1(2), 127-132. DOI: 10.1016/00032697(60)90004-X

Niranjane, A. P., Madhou, P., Stevenson, T. W. (2007). "The effect of carbohydrate carbon sources on the production of cellulase by Phlebia gigantea," Enzyme Microb. Technol. 40, 1464-1468. DOI: 10.1016/j.enzmictec.2006.10.041

Oberoi, H. S., Chavan, Y., Bansal, S., Dhillon, G. S. (2010). "Production of cellulases through solid state fermentation using kinnow pulp as a major carbon source," Food Bioprocess Technol. 3, 528-536. DOI: 10.1007/s11947-008-0092-8

Oszust, K., Pawlik, A., Janusz, G., Ziemiński, K., Cyran, M., Siczek, A., Gryta, A., Bilińska-Wielgus, N., and Frąc, M. (2017). "Characterization and influence of a multi-enzymatic biopreparation for biogas yield enhancement," BioResources 12, 6187-6206. DOI: 10.15376/biores.12.3.6187-6206

Pérez, J., Muñoz-Dorado, J., Rubia, T. D. L., and Mar, J. (2002). "Biodegradation and biological treatments of cellulose, hemicellulose and lignin: An overview," Int. Microbiol. 5(2), 53-63. DOI: 10.1007/s10123-002-0062-3

Pinzari, F., Ceci, A., Abu-Samra, N., Canfora, L., Maggi, O., and Persiani, A. (2016). "Phenotype MicroArray TM system in the study of fungal functional diversity and catabolic versatility," Res. Microbiol. 167, 710-722. DOI:

10.1016/j.resmic.2016.05.008

Pinzari, F., Reverberi, M., Piñar, G., Maggi, O., and Persiani, A. (2014). "Metabolic profiling of Minimedusa polyspora (Hotson) Weresub \& P. M. LeClair, a cellulolytic fungus isolated from Mediterranean maquis, in southern Italy," Plant Biosyst. 148, 333-341. DOI: 10.1080/11263504.2013.877536

Pointing, S. B. (1999) "Qualitative methods for the determination of lignocellulolytic enzyme production by tropical fungi," Fungal Div. 2, 17-33

Pokhrel, D., and Viraraghavan, T. (2005). "Treatment of pulp and paper mill wastewater-A review," World Pulp \& Paper 333(1), 37-58. DOI:

10.1016/j.scitotenv.2004.05.017

Raulo, R., Kokolski, M., and Archer, D. B. (2016). "The roles of the zinc inger transcription factors XlnR, ClrA and ClrB in the breakdown of lignocellulose by Aspergillus niger," AMB Express 6, 1-12. DOI: 10.1186/s13568-016-0177-0

Roest, K., Heilig, H. G., Smidt, H., Vos, W. M., Stams, A. J., and Akkermans, A.D. (2005). "Community analysis of a full-scale anaerobic bioreactor treating paper mill wastewater," Syst. Appl. Microbiol. 28(2), 175-185. DOI: 10.1016/j.syapm.2004.10.006

Romano, I., Giordano, A. L., Nicolaus, B., and Gambacorta, A. (2003). "Planococcus rifietensis $\mathrm{sp}$. nov, isolated from algal mat collected from a sulfurous spring in 
Campania (Italy)," Syst. Appl. Microbiol. 26(3), 357-366. DOI:

10.1078/072320203322497383

Sangma, C. B. K., and Thakuria, D. (2019). "Isolation and screening of cellulose degrading microorganisms from forest floor litters of Jhum Fallows," P. Natl. A. Sci. India. B. 89, 999-1006. DOI: 10.1007/s40011-018-1015-8

Shi, L., Shi, G., ZhuGe, R., Cheng, Q., Wu, F., and Ni, Y. (2018). "Identification and characterization of slime-producing microorganisms in papermaking water loops using emulsion polymerase chain reaction techniques," Journal of Bioresources and Bioproducts 3(3), 128-133. DOI: 10.21967/jbb.v3i3.176

Stursova, M., Zifcakova, L., Leigh, M. B., Burgess, R., and Baldrian, P. (2012). "Cellulose utilization in forest litter and soil: Identification of bacterial and fungal decomposers," FEMS Microbiol. Ecol. 80, 735-746. DOI: 10.1111/j.15746941.2012.01343.x

Su, F., Dong, L., Li, H., and Wang, T. (2018). "Influence of paper mill wastewater on reed chlorophyll content and biomass," Phys. Chem. Earth Pt A/B/C 108, 13-18. DOI: 10.1016/j.pce.2018.06.003

Taha, M., Kadali, K. K., Al-Hothaly, K., Smith, A. T., Ball A. S., and Adetutu, E. M. (2015). "An effective microplate method (Biolog MT2) for screening native lignocellulosic-straw-degrading bacteria," Ann. Microbiol. 65(4), 2053-2064. DOI: 10.1007/s13213-015-1044-y

Taniguchi, M., Tanaka, M., Matsuno, R., and Kamikubo,T. (1982). "Evaluation of chemical pretreatment for enzymatic solubilization of rice straw," Eur. J. Appl. Microbiol. Biotechnol. 14, 35-39. DOI: 10.1007/BF00508001

Teather, R. M., and Wood, P. J. (1982). "Use of Congo red-polysaccharide interactions in enumeration and characterization of cellulolytic bacteria from the bovine rumen," Appl. Environ. Microb 43(4), 777-80. DOI: 10.1111/j.1749-6632.1994.tb44394.x

Teymouri, M., Karkhane, M., Gilavand, F., Akhtari, J., and Marzban, A. (2018). "Extracellular lipase purification from a marine Planomicrobium sp. MR23K and productivity optimization in a pilot-scale submerged bioreactor," P. Natl. A. Sci. India B 88(2), 739-746. DOI: 10.1007/s40011-016-0812-1

Tirado, D. N., Ja' uregui, Tirado-Estrada, G., Mar, H., Arturo, P., Guevara, F., and Miranda, L. (2016). "Production of cellulases and xylanases by white-rot fungi cultured in corn stover media for ruminant feed applications," Anim. Feed Sci. Technol. 221, 147-156. DOI: 10.1016/j.anifeedsci.2016.09.001

Van, H. M., and Kazuo, K. (1985). "A new species of Planococcus, P. kocurii isolated from fish, frozen foods, and fish curing brine," J. Gen. Appl. Microbiol. 31(5), 441455. DOI: $10.2323 /$ jgam.31.441

Wen, Z., Liao, W., Chen, S. (2005). "Production of cellulase/ $\beta$-glucosidase by the mixed fungi culture Trichoderma reesei and Aspergillus phoenicis on dairy manure," Process Biochem. 40, 3087-3094. DOI: 10.1385/ABAB:121:1-3:0093

Yamakawa, Y., Endo, Y., and Li, N. (2013). "Regulation of cellulolytic genes by McmA, the SRF-MADS box protein in Aspergillus nidulans," Biochem. Biophys. Res. Commun. 431, 777-782. DOI: 10.1016/j.bbrc.2013.01.031

Yoon, J. H., Kang, S. S., Lee, K. C., Lee, E. S., and Park, Y. H. (2001). “Planomicrobium koreense gen. nov. sp. nov. a bacterium isolated from the Korean traditional fermented seafood jeotgal, and transfer of Planococcus okeanokoites (Nakagawa et al. . 1996) and Planococcus mcmeekinii (Junge et al. 1998) to the genus Planomicrobium," Int. J. Syst. Evol. Microb. 51(Pt4), 1511-1520. DOI: 


\subsection{9/00207713-51-4-1511}

Young, C., DuBok, Ch., and Kazuhiro, T., (2014). "Isolation of Bacillus sp. strains capable of decomposing alkali lignin and their application in combination with lactic acid bacteria for enhancing cellulase performance," Bioresource Technol. 152, 429436. DOI: $10.1016 /$ j.biortech.2013.11.032

Zainith, S., Purchase, D., Saratale, G. D., Ferreira, L., Bilal, M., and Bharagava, R. (2019). "Isolation and characterization of lignin-degrading bacterium Bacillus aryabhattai from pulp and paper mill wastewater and evaluation of its lignindegrading potential," 3 Biotech. 9(3), 92-103. DOI: 10.1007/s13205-019-1631-x

Zhang, D. C., Liu, H. C., Xin, Y. H., et al. (2009). "Planomicrobium glaciei sp. nov. a psychrotolerant bacterium isolated from a glacier," Int. J. Syst. Evol Microb 59(6), 1387-1390. DOI: 10.1099/ijs.0.002592-0

Zhao, K., Xue, P. J., and Guang (2008). "Study on determination of reducing sugar content using 3,5-dinitrosalicylic acid method," Food Sci. 2008(08), 534-536.

Zhu, Z., Sathitsuksanoh, N., Vinzant, T., Schell, D., Mcmillan, J., and Zhang, Y. (2009). "Comparative study of corn stover pretreated by dilute acid and cellulose solventbased lignocellulose fractionation: Enzymatic hydrolysis, supramolecular structure and substrate accessibility," Biotechnol. Bioeng. 103, 715-724. DOI: 10.1002/bit.22307

Zwieten, L. V., Kimber, S., Morris, S., Chan, K., Downie, A., and Rust, J. (2010). "Effects of biochar from slow pyrolysis of papermill waste on agronomic performance and soil fertility," Plant Soil 327(1/2), 235-246. DOI: 10.1007/s11104009-0050-x

Article submitted: October 15, 2019; Peer review completed: January 14, 2020; Revised version received and accepted: January 16, 2020; Published: January 24, 2020.

DOI: 10.15376/biores.15.1.1732-1746 